\title{
The Drivers of Consumer Value in the ECR Category Management Model
}

\author{
Christina Holweg ${ }^{*}$, Peter Schnedlitz ${ }^{* *}$ \\ Institute for Retailing and Marketing, Vienna University of Economics and Business, Vienna, \\ Austria \\ Christoph Teller ${ }^{* * *}$ \\ Institute for Retail Studies, University of Stirling, Stirling, United Kingdom
}

*... [corresponding author] Institute for Retailing and Marketing, Vienna University of Economics and Business, Augasse 2-6, A-1090 Vienna, Austria, Tel: ++43-1-31336-4620, Fax: ++43-1-31336-904620, Email: christina.holweg@wu-wien.ac.at

**...Institute for Retailing and Marketing, Vienna University of Economics and Business, Augasse 2-6, A-1090 Vienna, Austria, Tel: ++43-1-31336-4622, Fax: ++43-1-31336-717, Email: peter.schnedlitz@wu-wien.ac.at

***...Institute for Retail Studies, University of Stirling, Stirling FK9 4LA, United Kingdom, Tel: ++44 (0) 178646 6454, Fax: ++44 (0) 178646 5290, Email: christoph.teller@stir.ac.uk

Submitted to the International Review of Retail, Distribution and Consumer Research $1^{\text {st }}$ submission: 2 February 2009

$1^{\text {st }}$ reviews received: 30 March 2009

$2^{\text {nd }}$ submission: 10 June 2009

Accepted: 12 June 2009 


\title{
The Drivers of Consumer Value in the ECR Category Management Model
}

\begin{abstract}
This paper critically evaluates the proposed structure and contents of a frequently discussed Category Management (CM) model in the Efficient Consumer Response (ECR) context. Based on this we present an extensive empirical study where the data from a survey of 202 household representatives are merged with their actual purchasing data taken from a consumer purchase panel ( $>30,000$ purchase observations). The results from an exploratory factor analysis and subsequent multiple regression analyses show that the investigated CM model needs to be amended by personnel and Point-of-Sale aspects as they affect

Consumer Value significantly. Finally, the investigated differences between the drivers of Consumers Value call for including both survey and consumer purchase data and consequently incorporate attitudinal and behavioural aspects into Category Management.
\end{abstract}

Keywords: Efficient Consumer Response, Category Management, Consumer Value, consumer purchase panel, retail stores, grocery

\section{Introduction}

In the late 1990s, 'Efficient Consumer Response’ (ECR) led to a grocery revolution through a paradigmatic shift in focussing on the consumer as well as a new form of cooperation between retailers and suppliers (Kahn and McAlister, 1997). ECR conceptualises this consumer focus through 'Category Management' (CM) defined as “... a distributor/supplier process of managing categories as strategic business units producing enhanced business results by focussing on delivering consumer value” (ECRE, 1997).

Whilst optimising categories has always been an objective within retail management, the specific term of CM appears in the early 1990s in the USA as part of the ECR-strategy 'Efficient Store Assortment' and 'Efficient Store Merchandising' (Food Marketing Institute 1993). Consequently the need of cooperative approaches between retailers and suppliers has led to an evolved European ECR-model - the so called global scorecard - which distinguishes between logistics related matters and consumer related matters (ECR Europe, 2009). Therein, CM represents the so called 'Demand Management' depicted in Figure 1 and comprises the three strategies: 
'Optimise Assortments’, ‘Optimise Promotions’, 'Optimise New Product Introductions’. 'Collaborative Shopper Consumer Value Creation’ represents the objectives of CM and 'Demand Strategy and Capabilities' forms the strategic and organisational framework for the collaborative approach, also available on the side of Supply Management (for further details see e.g. Aastrup et al 2008; Finne and Sivonen, 2009).

Figure 1: CM as part of the ECR-Model / Global Scorecard

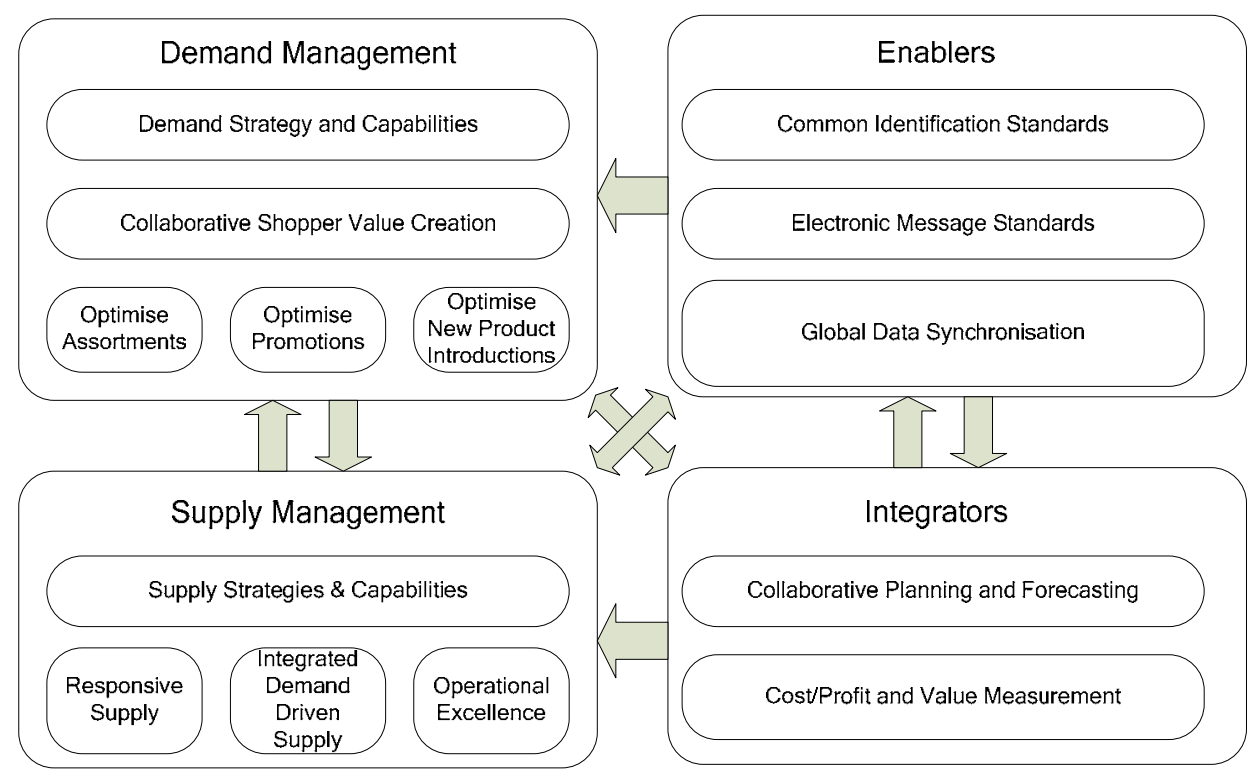

$\mathrm{CM}$ is executed in collaborative projects between retailers and suppliers and despite several obstacles in the beginning of the cooperation (Dussart 1998) it now can be regarded as a widely used and accepted tool in retailing. CM projects are executed according to the standardised '8-step process' (JIP, 1995; ECRE, 1997). With retailers and suppliers becoming more familiar with CM, some recent projects rely on a shortened ‘4-stage process’ denoted by ECR as “day-to-day Category Management” (ECRE, 2000) which aims at reducing complexity and transforming CM from a project basis to a process which can be integrated into firms’ daily operations. 
CM is regarded as the most important element of ECR by the vast majority of retailers and suppliers in the grocery industry (Schmickler and Rudolph, 2002). Furthermore, empirical evidence shows that the biggest potentials for economic performance originate from Demand Management related matters (Corsten, 2004). Smaller companies and even other sectors such as, for example, Do-It-Yourself retailers, fashion industry and pharmacies have also adapted this approach.

In this paper CM is understood in the conceptual setting explained above. Nevertheless, other definitions and understandings of CM do exist (e.g. MüllerHagedorn and Zielke, 2000; Mathews, 1995; Tietz, 1993). Despite its ubiquitous implementation, ECR and CM have been criticised by both academics and practitioners:

- From the academic perspective, Kotzab (1999) notes that ECR lacks a theoretical underpinning and that the definition of Consumer Value as the ultimate aim of ECR is difficult to measure and operationalise. Schroeder and Feller (2000) provide empirical evidence for the disregard of consumer-oriented data in CM.

- Practitioners criticise the lack of integrating the consumer's perspective (ACNielsen, 2006; Seifert, 2001), missing explicit emphasis on price and POS related aspects within the CM model (ECR Europe, 2006; Schroeder, 2001) and point out the decreasing benefits with the repetition of CM projects (ECR Europe, 2007).

Despite the initial euphoria regarding CM we still face a lack of discussion and consideration in the literature with respect to these shortcomings (Dussart, 1998). In addition to this, only a few attempts have been undertaken to advance the proposed CMapproach. However, in this paper we will take a critical look at a most frequently applied CM model and investigate - independent of the so far proposed structure - the drivers of Consumer Value in terms of bundles of instruments which are of strategic importance for both retailers and suppliers. Consequently, the focus of this paper is to 
deal with the following two questions: (1) Are the three stated strategies of Optimise Assortments, Optimise Promotions and Optimise New Product Introductions exhaustive in delivering Consumer Value? Therein the underlying thought is that the decreasing benefits within the investigated CM approach may be attributed to a lack of other key factors that deliver Consumer Value in the long-run. (2) What is the relative impact of each strategy on Consumer Value? Uneven impacts would suggest a prioritisation regarding the application of strategies for retailers and suppliers.

The structure of this paper is as follows: After this introductory section we identify seven research streams in the CM related literature. Based on this review we propose a conceptual framework that is empirically tested by using data from a household survey merged with actual purchasing data taken from a consumer panel. After elaborating on the applied research design the results of an exploratory factor analysis and multiple regression analyses are presented and consequently discussed with reference to the existing literature. Limitations and directions for further research conclude the paper.

\section{Literature Review}

CM has been extensively discussed in literature dealing with Supply Chain Management, Retailing and Marketing. The majority of articles are based on single case studies or recommendations from consultants and practitioners (Dewsnap and Hart, 2004). The number of research papers based on rigorous empirical studies is still quite limited. In order to give a structured overview of this very heterogeneous field of publications, we have identified the following seven research streams (Holweg, 2009):

(1) Implementation level of CM: Publications in this stream follow a descriptive approach and focus on the level of implementation of CM by retailers and suppliers across Europe and the USA. The core findings can be characterised as follows: In 1996, 
$40 \%$ of retailers and suppliers had implemented CM in the USA, in Europe approximately $20 \%$ of companies had finalised an implementation whilst more than $50 \%$ intended to do so (Wuest and KSA, 1996). In 2005, more than nine out of ten retail companies in the UK and in the German speaking countries practise CM (GS1 Germany, 2008; IGD, 2006). Borchert (2001) found out that smaller companies were less involved and less successful when using CM. Over time, the standard 8-step CM process has been adapted and streamlined by most retailers and suppliers (IGD, 2006).

(2) Mainly conceptual discussions of CM: Studies and publications included in this stream focus on CM from a merely conceptual perspective. For example, Laurent (1996) classifies CM as a type of vertical cooperation characterised as a market-oriented project which is realised within a limited period of time. In contrast, cooperations in the area of ECR Supply Management are merely process-oriented aiming at the application of common standards that are integrated into the day-to-day business (Kotzab and Teller, 2003). Holzkämper (1999) looks at CM from a strategic retail perspective by applying the theory-of-strength. By applying the system theory approach Moll (2000) analyses CM in a holistic way. Thereby, he stresses that involving the consumer perspective is crucial for the success of CM. Aastrup et al (2008) integrate CM into a model which structures and links the various ECR-measures. Schroeder (2001) notes that CM-models lack the consideration of the strategy ‘Efficient Shelf Presentation’ and thus (visual) merchandising matters.

(3) Selective consideration of CM-strategies: The third stream of studies is related to the three strategies of 'assortment', 'promotion' and 'new product introduction'. Regarding the optimisation of assortments several studies have analysed the effect of assortment reduction and its effects on consumer's perception and shopping behaviour (e.g. Rudolph and Kotouc, 2007; Broniarczyk et al., 1998) as well 
as prices and profit (e.g. Basuroy et al., 2001; Grewal et al., 1999). As an overall result, assortment reductions up to $25 \%$ on less preferred products are feasible without negative effects on consumer’s perceptions and retail sales. Directly linked to optimising assortments are studies which investigate the driving factors that lie behind consumers’ decisions for national brands and store brands (e.g. Rondán Calaluña et al. (2000)), studies which deal with the optimisation of shelf planograms based on consumers’ product choice process (e.g. Zielke 2001; Mollá et al., 1998) and studies focussing on consumers’ reactions on product delisting and out-of-stock situations (e.g. Verbeke et al., 2000).

The focus on promotions within the CM-concept can be found in studies which deal with the role of categories and with the critical relationship between national and store brands. Narashiman et al. (1996) reveal that price elasticity is different between categories which should lead to a selective use of promotion strategies. Ailawadi et al. (2001) found that promotions on store brands and national brands are targeting different consumer groups. Consequently, they call for optimising communication concepts by taking into consideration segment specific characteristics of consumers. Kamakura and Kang (2007) look at cross-brand and cross-category effects of price promotions. They conclude that promotions on leading brands are most effective as brand switchers are attracted to the highest degree.

Regarding the strategic area of new product introduction the meta-analysis of Henard and Szymanski (2001) shows that factors like e.g. the core benefit proposition of a product, an in-depth understanding of consumers' needs and clear market definitions determine the success of new product performance. Sivadas and Dwyer (2000) underscore that 'cooperative competency' is the key factor on successful new 
product development. This emphasises the benefits of a joint product development process including retailers and suppliers.

(4) Consumer Value: The topic of Consumer Value - often used synonymously for Customer or Shopper Value - has been extensively discussed in the literature (e.g. Verhoef et al., 2007; De Kervenoael et al., 2006; Woodruff 1997; Parasuraman, 1997; Holbrook, 1994; Zeithaml 1988). Besides the various definitions, ECR views Consumer Value as a concept which aims at building bonds and with consumers to ultimately generate profitable growth (ECRE, 1999). To achieve this, the use of data on consumer behaviour proves to be essential within the 8-step CM process (Desrochers and Nelson, 2006; Dussart, 1998). Similarly, Johnson and Pinnington (1998) propose the use of additional market research approaches leading to better consumer understanding and better category strategies.

(5) Success factors of CM: The fifth research stream deals with success factors of CM. Gruen and Shah (2000) evaluate that the implementation of CM plans has a higher impact on category performance than the objectivity of the supplier when proposing the category plan. Dhar et al. (2001) identify four distinguishing groups of categories. For each group they suggest a specific application of marketing instruments with respect to assortment, price and promotion. IGD (2006) specifies the lack of time, financial resources and skilled personnel as the key obstacles when implementing CM.

(6) Retailer-supplier relationship: This research stream deals with the influences and impact of CM on the retailer-supplier relationship. Such studies tend to reveal that CM contributes to a partial development of mutuality and the tendency for retailers to move from coercive power to a more cooperative approach (Hingley, 2005; Dapiran and Hogarth-Scott, 2003). Therefore, cooperation can be characterised by trust between retailer and supplier which is a confirmed key prerequisite for successful CM (Dupre 
and Gruen, 2004). For retailers, this shift from negotiation towards relationship means sacrificing bargaining power and control over marketing tactics (Aastrup et al., 2007) even though the ultimate bargaining power lies with the retailer (Lindblom and Olkkonen, 2006). For suppliers, the relationship effect of CM seems to depend on their role relative to their competitors: suppliers of a category that regard themselves as being strong players in the market have a stronger influence on tactical CM decisions compared to less powerful suppliers (Lindblom and Olkkonen, 2008). The disadvantage of smaller suppliers needs to be addressed by an objective role of so called 'Category Captains' (i.e. the most innovative and powerful suppliers within the category) and retailers' critical evaluation of the proposed category plans (Kurtulus and Toktay, 2005).

(7) Organisational aspects of CM: The last stream refers to the organisational dimension and how CM is best implemented in a firm. Overall, CM has led to a multifunctional team approach on both the supplier and retailer side in contrast to the traditional single point of contact structure of retail buyers and key account managers (Fernie, 2009; ECRE, 1997). The implementation of CM is stabilising in such a way that the majority of retailers work with CM teams, whilst suppliers dedicate CM responsibilities to either specialist teams, trade marketing teams or key account managers (GS1 Germany, 2008; IGD, 2006).

Following this literature review, encompassing the academic and the practitioners' perspective, two points need to be highlighted with reference to the CM model: Firstly, CM, as per ECR, assumes that it is suited for all categories of a retail store and can thus be used as a kind of generic approach that is suitable for optimising product categories of different kinds. Studies of CM are however indicating that CM is best applicable for categories containing packaged products (see e.g. Dhar et al., 2001). 
Approximately one third of a retail store's turnover lies in strategically important categories such as fresh fruit or in serviced food categories including fresh bakery products or meat (ACNielsen, 2006a). Secondly, the identified literature - no matter to

which stream it is categorised - neither critically discusses the concept of CM per se nor does it provide empirical evidence for the proposed structure of a CM model. This includes a lack of consideration of the effects between the marketing instruments used to support the three strategies and Consumer Value.

\section{Conceptual framework}

ECR defines Consumer Value as "providing of functional and emotional benefits tailored to the individual needs of consumers that continuously enhance their overall life experience” (ECRE, 1999). This understanding of value is different to the various definitions of the terms of Consumer or Customer Value in literature (e.g. Woodruff, 1997; Parasuraman, 1997; Holbrook, 1994; Zeithaml, 1988). Importantly, other ECRsources relate Consumer Value to “creating enthusiasm” or "building superior bonds with consumers” aiming at creating consumer loyalty towards, for example brands and stores (ECRE, 1999; ECRE, 1999a). Consumers "who feel so strongly that you can best meet his and her relevant needs that your competition is virtually excluded from the consideration set” are defined as “true loyal customers” (Shoemaker and Lewis, 1999). Loyalty is operationalised by both behavioural measures (e.g. expenditures, share of spending) as well as attitudinal measures (e.g. likelihood of usage, recommendation to friends) in the extant literature (e.g. Kumar and Shah, 2004; Reichheld, 2003). This two-dimensional measurement is in line with how ECR operationalises Consumer Value (ECRE, 1999). Thus, this paper adopts this original ECR-terminology of Consumer Value. Consequently, Consumer Value can be operationalised by the following six variables outlined in Table 1 . They include satisfaction and patronage 
intentions as attitudinal variables (Reichheld, 2003; Woodruff, 1997), and spending and shopping frequency as behavioural variables. The latter two are also seen in relative terms as loyalty (share of spending) and relative frequency (share of choice).

Table 1: Operationalisation of Consumer Value

\begin{tabular}{|c|c|c|}
\hline Value measures & Indicator & Literature \\
\hline \multicolumn{3}{|c|}{ 'Value delivered to consumers' - attitudinal dimension } \\
\hline $\begin{array}{l}\text { 1. Consumer } \\
\text { satisfaction }\end{array}$ & $\begin{array}{l}\text { Overall satisfaction rating with a } \\
\text { retailer (6-point rating scale) }\end{array}$ & $\begin{array}{l}\text { e.g. Parasuraman et al., 1988; Woodruff, 1997; } \\
\text { ECRE, 1999; Fornell et al., } 1996\end{array}$ \\
\hline $\begin{array}{l}\text { 2. Patronage intentions } \\
\text { (mean value of } 2 \mathrm{a} \text { and } \\
\text { 2b) }\end{array}$ & $\begin{array}{l}\text { 2a. Intention to visit a store } \\
\text { (6-point rating scale) } \\
\text { 2b. Willingness to recommend to others } \\
\text { (6-point rating scale) }\end{array}$ & $\begin{array}{l}\text { e.g. Baker et al., 2002; Sirohi et al., 1999; } \\
\text { ECRE, 1998; Dodds et al., } 1991 \\
\text { e.g. Reichheld, 2003; Baker et al., 2002; Sirohi } \\
\text { et al., 1999; ECRE, 1999; Zeithaml et al., } 1996\end{array}$ \\
\hline \multicolumn{3}{|c|}{ ‘Value received from consumers' - behavioural dimension } \\
\hline 3. Spending & Absolute spending at a store $(€)$ & \\
\hline 4. Shopping frequency & Absolute number of visits at a store (\#) & \\
\hline 5. Loyalty & $\begin{array}{l}\text { Share of spending regarding a store } \\
\text { (relative to total spending) (\%) }\end{array}$ & $\begin{array}{l}\text { e.g. Kumar and Shah, 2004; Churchill and } \\
\text { Iacobucci, 2002; ECRE, } 1999\end{array}$ \\
\hline 6. Relative Frequency & $\begin{array}{l}\text { Share of visits regarding a store } \\
\text { (relative to all visits) (\%) }\end{array}$ & \\
\hline
\end{tabular}

In general the degree of Customer Value can be influenced by the perception of attributes of products, categories and consequently the shopping environment such as the store or the retail agglomeration (Teller et al., 2008; Woodruff, 1997; Woodside and Trappey, 1992). These attributes are perceived characteristics of a store being as the result of the use of marketing instruments (Reutterer and Teller, 2009). Following ECR, the marketing instruments (also called 'tactics') included in the CM model are assortment, price, promotion and shelf space allocation (ECRE, 1997). Further marketing instruments mentioned in literature are quality, service/convenience, merchandising/PoS (Point-of-sale), personnel, location and communication (see for example, Gilbert, 2003; Berekoven, 1995). All these marketing instruments are included in a generic model according to the objective of CM. Consequently, this model is applicable to different kinds of categories within retail stores and includes key strategic areas which ultimately drive Consumer Value, e.g. Optimise Assortments. The key strategic areas are reflected in the collaborative 8-step CM process in which the tactical 
instruments are then put into place. Thus, the set of six dependent variables and nine marketing instruments leads to the research model depicted in Figure 2.

Figure 2: Research model and operationalisation of variables

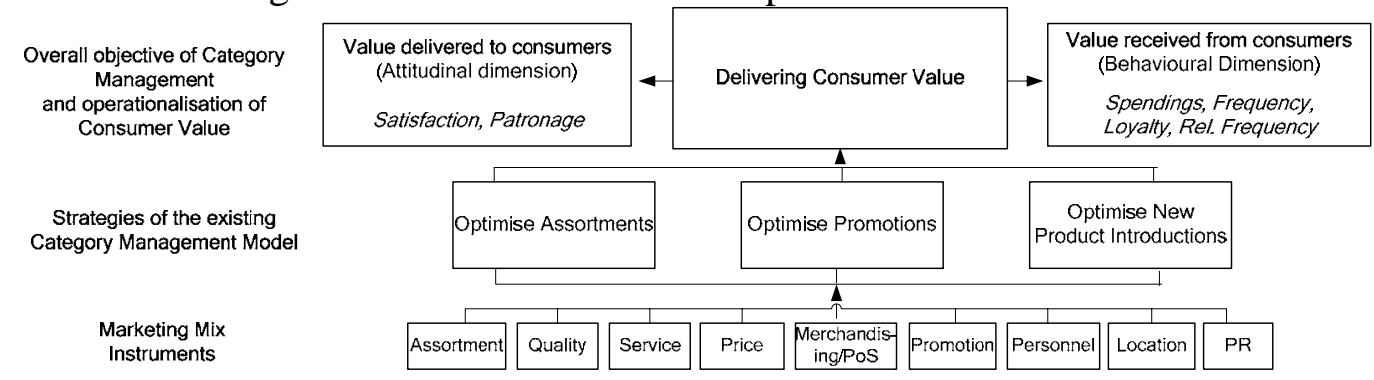

All the above instruments can be seen as marketing instruments relevant to both retailers and suppliers. Only location is a pure retailer instrument but is included for the sake of completeness and in order to comparing its impact on Consumer Value relative to the other instruments.

This model is based on two propositions:

$\mathrm{P}_{1}$ : The depicted three strategies of the current ECR CM model are reflected by the set of marketing instruments. The recently included instruments such as merchandising/POS or personnel have been not considered by ECR because they are not seen to affect Consumer Value.

$\mathrm{P}_{2}$ : The three strategies of the CM model have an even impact on Consumer Value. Consequently, the existing CM model does not explicitly suggest any prioritisation of these strategies regarding the impact on Consumer Value.

The propositions account for two implicit assumptions standing behind the investigated CM model. The first is the proposed relationships between the objective, the three strategies and the tactical instruments. The second related to the proposed even impact of these strategies on Consumer Value. 


\section{Empirical Study}

\section{Research Design}

To test our propositions we targeted those who held the main responsibility of purchasing groceries for their households. In order to construct both attitudinal and behavioural data a 'Single Source Approach’ was employed. Based on the national consumer purchase panel of GfK-Austria we conducted a web-based survey using a self-administered, standardised questionnaire which included 65 closed questions (Grant et al., 2005). The nine marketing instruments in the model are measured by 40 indicators most frequently used in literature (see e.g. Grewal et al., 2006; Teller et al., 2006; Baker et al., 2002; Sweeney and Soutar, 2001; Handelman and Arnold, 1999; van Kenhove et al., 1999; Broniarczyk et al., 1998; Erdem and Swait, 1998; Sirohi et al., 1998). Noticeably, the strategy New Product Introductions is reflected in the variable ‘availability of new products'. Public Relations related indicators included items such as 'supports Austrian tradition/culture'. Thereby we paid tribute to retailers new communication strategies which include for example perceptions of corporate social responsibility (CSR) (see e.g. Luo and Bhattacharya, 2006). All indicators were measured on a 6-point rating scale (1=totally agree; 6=totally disagree).

The survey data measuring respondents’ perception of actually patronised retail stores was consequently merged with their actual purchasing data. The latter was constructed by observing more than 30.000 purchasing transactions over a 10 months period based on a net sample of 202 respondents from which 1,297 store evaluations were retrieved. The characteristics of respondents reflected the profile of the national consumer purchase panel and thus those of all Austrian household representatives and households with reference to key criteria (size of household, number of children in the household, size of residential area). Table 2 provides an overview of the applied research design (Holweg, 2009). 


\section{Table 2: Research Design}

$\begin{array}{ll}\text { Research method } & \begin{array}{l}\text { Web-based consumer survey within the national consumer purchase } \\ \text { panel by GfK Austria (N=2,800 households ) } \\ \text { Research instrument }\end{array} \\ \begin{array}{l}\text { Self-administered standardised questionnaire with } 65 \text { closed } \\ \text { questions }\end{array} \\ \text { Quota sample of } 300 \text { questionnaires (quota controls: size of } \\ \text { household, age of the household leader, net-income, number of } \\ \text { children up to } 14 \text {, size of city) } \\ \text { Full coverage of the Austrian Food sector including Hofer/Aldi, i.e. } \\ \text { Retail sample } & \begin{array}{l}14 \text { retailers representing the three dominant store formats, i.e. } \\ \text { supermarket, hypermarket and discount store } \\ 202 \text { questionnaires (67\%) }\end{array} \\ \text { Return rate } & 1,297 \text { evaluation of retail stores ; n=1,297 } \\ \text { Final sample } & 10 \text { months purchase period (>30,000 buying transactions) } \\ \text { Time period of panel audit } & \text { Factor analysis, multiple regression analyses } \\ \text { Analysis method } & \text { SPSS 14.0, GfK-CatMan } \\ \text { Analysis tools } & \end{array}$

\section{Results}

To test the two propositions a two-step analysis approach was applied:

Firstly, an exploratory factor analysis was conducted in order to identify the key dimensions behind the included indicators operationalising retailers' marketing instruments (see Figure 2). Based on the respondents’ ratings six factors were identified. These factors can be seen as bundles of instruments that are of strategic importance for both retailers and suppliers in CM. Table 3 depicts the result of the exploratory factor analysis.

Factor 1 represents the most important factor thus being an absolute $17 \%$ of the $59 \%$ of the total explained variance. It primarily comprises assortment-related indicators but also includes quality/freshness and service-related indicators. This indicates that the assortment - from a consumer's point of view - is inseparably linked to quality and service aspects. Factor 1 can be described as ‘Assortment/Quality/Service’. 
Table 3: Result of the exploratory factor analysis

\begin{tabular}{|c|c|c|c|c|c|c|}
\hline Indicators*) & 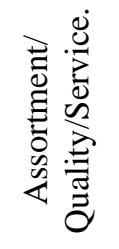 & 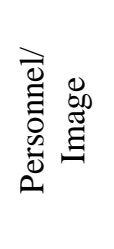 & 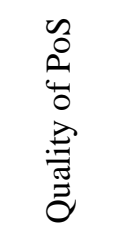 & 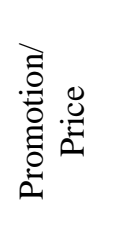 & 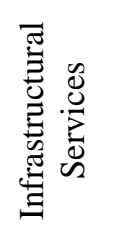 & 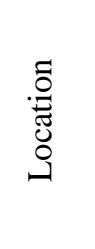 \\
\hline Broad availability of branded products & .761 & & & & & \\
\hline Possibility to recycle glass bottles & .729 & & & & & \\
\hline Attractive Loyalty Programmes & .696 & & & & & \\
\hline Offer of organic products & .672 & & & & & \\
\hline Fresh bread and bakery products & .662 & & & & & \\
\hline Good service with cheese, bread, etc. & .660 & & & & & \\
\hline Broad variety of Austrian products & .584 & & & & & \\
\hline Broad variety of meat and sausages & .580 & & & & & \\
\hline Broad variety of Drug Store products & .577 & & & & & \\
\hline Active in training of employees & .526 & & & & & \\
\hline Broad variety of diary products & .524 & & & & & \\
\hline Leading the topic of balanced diet & .511 & & & & & \\
\hline Broad variety of fruits and vegetables & .501 & & & & & \\
\hline Availability of new products & .482 & & & & & \\
\hline Supporting Austrian tradition/ culture & .434 & & & & & \\
\hline Good availability of Sales Personnel & & .747 & & & & \\
\hline Personnel is well trained & & .672 & & & & \\
\hline Personnel is friendly & & .644 & & & & \\
\hline Short check-out lines & & 636 & & & & \\
\hline Well-arranged merchandise & & .582 & & & & \\
\hline Secures Austrian employment & & .573 & & & & \\
\hline Kind retailer & & .547 & & & & \\
\hline Fresh products offered within expiry date & & .453 & & & & \\
\hline Availability of products needed & & .405 & & & & \\
\hline Clean, tidy store & & & .689 & & & \\
\hline Positive picture in the public & & & .669 & & & \\
\hline Pleasant shopping atmosphere & & & .614 & & & \\
\hline Very good overall quality & & & .606 & & & \\
\hline Broad variety of products & & & .578 & & & \\
\hline Attractive promotions & & & & .712 & & \\
\hline Low priced & & & & .646 & & \\
\hline Advertising stimulates purchase & & & & .585 & & \\
\hline Striking advertising & & & & .520 & & \\
\hline Good value for money & & & & .508 & & \\
\hline Attractive private labels & & & & .425 & & \\
\hline Sufficient parking lots & & & & & .590 & \\
\hline Clear price marking & & & & & .480 & \\
\hline Convenient opening hours & & & & & .468 & \\
\hline Located nearby & & & & & & .844 \\
\hline Good accessibility & & & & & & .820 \\
\hline $\begin{array}{l}\text { Explained variance (\%; rotated sum of } \\
\text { loadings) }\end{array}$ & 17.330 & 14.091 & 10.848 & 7.261 & 4.887 & 4.429 \\
\hline Cronbach $\alpha$ & 0.921 & 0.897 & 0.883 & 0.692 & 0.452 & 0.724 \\
\hline
\end{tabular}

Notions: The matrix displays the rotated factor loadings. Loading below .5 is excluded from interpretation. Numbers in italics indicate variables which also load onto other factors. Interpretation is regarded as limited.

Principle components analysis; Varimax rotation; Measure of sampling adequacy-KMO =.961 (marvellous); Barlett-Test of Sphericity $\chi 2=29,635.29$; $\mathrm{df}=780 ; \mathrm{p}<.001$ (=Indicators sufficiently correlated)

Caption: *) Indicators as most frequently used in literature (e.g. Luo and Bhattacharya, 2006; Grewal et al 2006, Baker et al 2002, Sweeney/Soutar 2001, Handelman/Arnold 1999, van Kenhove et al 1999, Broniarczyk et al 1998, Erdem/Swait 1998, Sirohi et al 1998) 
Factor 2 includes all personnel-related indicators such as availability, competence and friendliness of sales personnel in addition to aspects relating to retailer's service image. Consequently, the retailer's service image is closely associated with a consumer's perception of its personnel. Factor 2 denotes 'Personnel/Image’ and explains another $14 \%$ of the total variance. Factor 3 shows the highest loadings of indicators related to the POS. Importantly, these indicators comprise qualitative aspects of the POS such as 'cleanliness' or 'atmosphere'. Indicators related to the merchandising including ‘availability of products' or 'well-arranged merchandise’ are already subsumed in factor 2. Factor 3 can be denoted as 'Quality of Point-of-Sale' and contributes an additional $11 \%$ to the explanation of variance. Factor 4 includes most of the promotion and price-related indicators ('Promotion/Price’). At 7\% of variance it explains less in comparison to factors 1 to 3 . Factor 5 subsumes variables describing 'Infrastructural Services'. The last factor clearly contains location related items and is denoted as 'Location'. The last two factors contribute another $4 \%$ to the explanation.

Based on these results our first proposition cannot be confirmed. The proposed structure of the CM model proves to be different and reveals additional strategic factors in terms of possible drivers of Consumer Value (see Figure 2).

In a next step, multiple regression analyses were conducted in order to investigate the impact of the identified strategic factors on Consumer Value. The result of the six separate analyses conducted with each of the dependent attitudinal and behavioural variables is summarised in Table 4. 
Table 4: Standardised Beta-Coefficients of the six constructs of Consumer Value

\begin{tabular}{|c|c|c|c|c|c|c|c|c|c|c|c|c|}
\hline \multirow{3}{*}{$\begin{array}{l}\text { Consumer } \\
\text { Value } \\
\text { Construct } \\
\text { Ranking }\end{array}$} & \multicolumn{4}{|c|}{$\begin{array}{l}\text { ATTITUDINAL DIMENSION } \\
\text { 'Value delivered to consumers' }\end{array}$} & \multicolumn{8}{|c|}{$\begin{array}{l}\text { BEHAVIOURAL DIMENSION } \\
\text { 'Value received from consumers' }\end{array}$} \\
\hline & \multicolumn{2}{|c|}{ Satisfaction } & \multicolumn{2}{|c|}{ Patronage } & \multicolumn{2}{|c|}{ Spending } & \multicolumn{2}{|c|}{ Loyalty Rate } & \multicolumn{2}{|c|}{ Frequency } & \multicolumn{2}{|c|}{ Frequency Rate } \\
\hline & Factor & Beta & Factor & Beta & Factor & Beta & Factor & Beta & Factor & Beta & Factor & Beta \\
\hline 1 & Pers/Img & .462 & Prom/Pr & .420 & Location & -.179 & Location & -.227 & Location & -.246 & Location & -.277 \\
\hline 2 & Prom/Pr & .358 & Pers/Img & .395 & Ass/Qul & -.176 & Ass/Qul & -.183 & Ass/Qul & -.186 & Ass/Qul & -.196 \\
\hline 3 & PoS/Qul & .358 & PoS/Qul & .310 & Pers/Img & -.159 & Prom/Pr & -.164 & Pers/Img & -.151 & Pers/Img & -.156 \\
\hline 4 & Ass/Qul & .174 & Location & .249 & Prom/Pr & -.115 & Pers/Img & -.154 & Prom/Pr & $-.088 *$ & Prom/Pr & -.114 \\
\hline 5 & Location & .147 & Ass/Qul & .184 & PoS/Qul & n.s. & PoS/Qul & -.099 & Infr/S & $.080 *$ & Infr/S & $.085 *$ \\
\hline 6 & $\operatorname{Infr} / \mathrm{S}$ & n.s. & $\operatorname{Infr} / \mathrm{S}$ & n.s. & Infr/S & n.s. & Infr/S & n.s. & PoS/Qul & n.s. & PoS/Qul & n.s. \\
\hline Adjusted $\mathrm{R}^{2}$ & \multicolumn{2}{|c|}{.521} & \multicolumn{2}{|c|}{.522} & \multicolumn{2}{|c|}{.080} & \multicolumn{2}{|c|}{.113} & \multicolumn{2}{|c|}{.115} & \multicolumn{2}{|c|}{.137} \\
\hline
\end{tabular}

Remarks:

All T-values show a high significance of $\mathrm{p}<.001$ except for results marked with $*(\mathrm{p}<.01)$

Pers/Img = Personnel/Image as a component of the factor analysis. Prom/Pr $=$ Promotion/Price,

PoS/Qul... Quality of POS, Ass/Qul = Assortment/Quality/Service, Infr/S...Infrastructural Services 
Five strategic factors show a significant impact on overall satisfaction $(\mathrm{p}<.05)$. The strongest impact on a consumer's overall satisfaction results from Personnel/Image (Beta=.462). The strategic factor of Promotion/Price and Quality of POS follow on in second and third place, respectively. Interestingly, Assortment/Quality/Service shows a lower impact as does Location.

The second attitudinal variable patronage is also affected by five strategic factors with highest significance $(\mathrm{p}<.05)$. The intention therein to revisit a store and to recommend it to others shows the strongest effect with respect to Promotion/Price (Beta=.420). Personnel/Image turns out to be the second strongest factor while Assortment/Quality/Service shows the smallest impact.

In comparison to the ranking of factors on consumer attitudes, the results from regression analyses including behavioural variables show a quite different picture. The absolute spending of a household is affected by four of the six strategic factors. Quality of PoS shows no significant impact whereas Location is displayed as the strongest influencing factor, indicating that proximity and accessibility have the highest impact on the amount spent with a retailer. Assortment/Quality/Service turns out to be the second most important factor, followed by Personnel/Image and Promotion/Price ${ }^{2}$.

The loyalty rate is significantly affected by five strategic areas. Again, Location and Assortment/Quality/Service prove to be the strongest influencing factors. However, Promotion/Price is ranked third, ahead of Personnel/Image which indicates the importance of this factor on consumer loyalty to a retailer. The absolute and relative frequency is significantly impacted by four strategies. Location and Assortment/Quality/Service again score first and second, respectively. Importantly, 
Personnel/Image comes third ahead of Promotion/Price as the supposed frequency drivers.

Consequently, our second proposition can not be confirmed since the strategic factors show different impacts on the six variables of Consumer Value. Furthermore, these results show the relative importance of each strategic factor on Consumer Value. Finally, it is worth mentioning that the model fit (adjusted $\mathrm{R}^{2}$ ) shows a considerable difference between the dimensions of attitude and behaviour. On the two attitudinal measures (satisfaction, patronage), $\mathrm{R}^{2}$ is approximately .5 indicating that about half of the variance on these two variables can be explained by the six factors. In terms of the four behavioural dimensions $\mathrm{R}^{2}$ ranges between low .080 and .137. This highlights the difficulty of explaining consumer behaviour in the grocery retail industry even by including 40 highly relevant indicators (Fassnacht et al., 2009). ${ }^{3}$

\section{Discussion}

By referring to the existing CM model and its included strategies, the results can be interpreted as follows. The high importance of the existing CM-strategy Optimise Assortments corresponds to fact that assortment is the core competency of many retailers (Levy and Weitz, 2006). Nevertheless, the consumer's point of view indicates the high relevance of quality and service related aspects (e.g. Baker et al., 2002; Richardson et al., 1994). This leads to the broader definition of this strategy as ‘Assortments/Quality/Service’. Specifically, this opens up new opportunities for both retailers and suppliers compared to just optimising the number of SKUs in a category based on EPOS data. A better understanding of customers building on consumer insights (Desrochers and Nelson, 2006; Johnson and Pinnington, 1998) will be essential for creating an assortment which also includes service related aspects which is of particular relevance in all serviced food areas. 
'Personnel/Image' turns out to be the second most important factor influencing Consumer Value. This confirms previous studies that show the high relevance of service quality in retail stores (e.g. Sweeney and Soutar, 2001; Zeithaml et al., 1996). It portrays an entirely new dimension that is not yet reflected in CM. This strategy is relevant for all categories that involve personnel, but, realistically, less important for most non-food categories which are sold in self-service. Optimising the factor personnel will require new areas of cooperation between retailers and suppliers (e.g. joint training, exchange of category knowledge).

'Promotion/Price’ reflects the existing CM-strategy of Optimise Promotions. However, it further includes price-related aspects which the CM model only currently displays at the level of marketing instruments. This pays tribute to the call for a pricerelated strategy expressed by the ECR-Demand Side (ECR Europe, 2006).

The fourth important strategic factor of 'Quality of PoS' brings in another new dimension. It shows the importance of qualitative aspects of the PoS such as cleanliness or atmosphere in comparison to the current limitation on shelf space allocation. It also confirms critical notions regarding the lack of integrating of PoS at the strategic level in the CM model (Schroeder, 2001). This strategic factor will also lead to new areas of cooperation between retailers and suppliers in optimising the entire of POS. 'Location' turns out to be a retailer's strongest performance driver confirming the result of previous studies (e.g. Reutterer and Teller, 2009; Reinartz and Kumar, 1999).

Based on these findings Figure 3 provides an extension of the existing CM model including the according four strategies (Holweg, 2009). Notably, the illustration does not include the factor Location as it is judged not to be an area of joint cooperation between suppliers and retailers. 
Figure 3: A potential extended CM Model based on empirical results

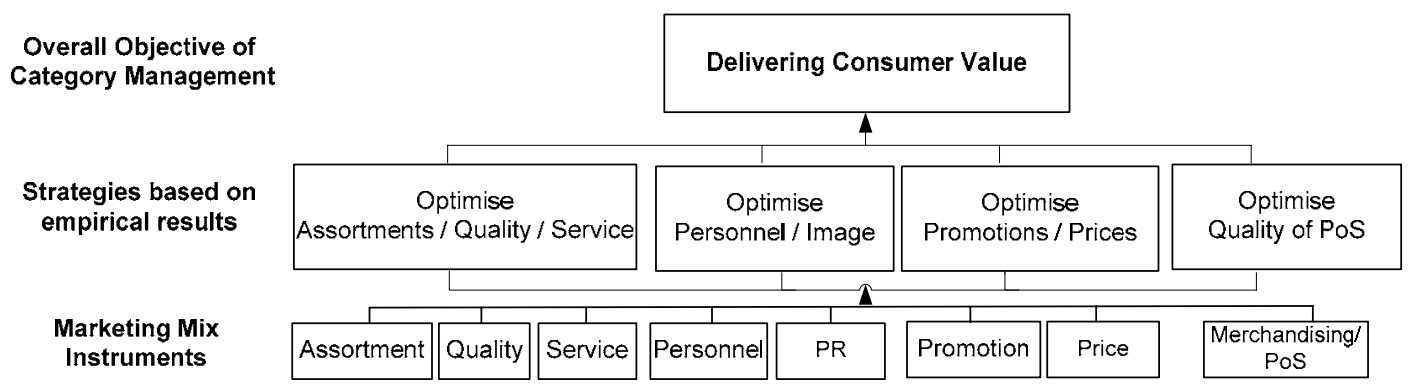

\section{Conclusions}

The paper makes a critical and empirical contribution to the field of CM by incorporating early critiques from the academic side about the missing conceptual basis of CM (Kotzab, 1999). The factor analysis suggest an amended structure of the investigated CM model and the regression analyses show the relative impact of the included marketing instruments upon the various dimensions of Consumer Value. This leads to a clear relationship hierarchy amongst these instruments. These results can help retailers to optimise their resource allocation and suppliers to better understand the category related needs of retailers.

The results also show the gap between consumers' cognitive statements and their actual behaviour an issue discussed at length in the literature (e.g. Glasman and Albarracin, 2006). This calls for the use of both attitudinal and behavioural consumer data depending on which success variable a retailer plans to impact. Limiting the analysis of CM to EPOS data only inhibits a broader consumer understanding as previously pointed out in literature (AC Nielsen, 2006; Schroeder and Feller, 2000). Thus the additional use of quantitative, consumer oriented data (e.g. consumer purchase panel data, retailer's CRM-data) as well as qualitative data (e.g. interviews, observations at the POS) can lead to a more profound consumer understanding as the basis for generating ‘true loyalty’ and profitability (Kumar and Shah, 2004). 
The inclusion of additional qualitative dimensions in regards to assortment and Point-of-Sale broadens the scope of CM. It also calls for further training and improving the skills of personnel on both the retailer and supplier side. This however proves to be amongst the actual key challenges in CM (IGD, 2006; Kurnia and Johnston, 2003).

The impact of promotion and price on Consumer Value seems to be overestimated in CM. Although the factor of Promotion/Price shows a considerable effect on a consumer's attitude towards a retailer, it plays a subordinate role for consumers' actual purchase behaviour. The finding calls for a prioritisation of strategies related to assortment and personnel over Promotion/Price which can be seen as further source of differentiation besides the aggressive and value deteriorating pricing activities in the retailing sector.

These findings indicate the potential of continuing the CM approach - but in an extended way. An application of the proposed CM model will require the use of additional data and resources as well as enhanced templates within the 8-step as well as the shortened 4-stage CM process.

\section{Limitations and Outlook for Further Research}

The results of our empirical study have to be interpreted with respect to the following limitations. The applied research design neglects situational aspects, e.g. task definition, time pressure of shopping trips which is found to have a substantial effect on the evaluation of retail stores (e.g. Reutterer and Teller, 2009; Teller and Reutterer, 2008; Van Kenhove et al., 1999). With regard to the generalisation of results, it has to be mentioned that the Austrian retail market has certain characteristics, i.e. high store density and high concentration. The analysis of data collected in other, and in particular Non-European, markets may lead to different 
results. Finally, the low model fit on the behavioural dimension shows the difficulty in explaining consumer behaviour even with an extensive Single Source Approach. This low fit can be explained by the habitual purchase behaviour of consumers in low interest categories. Therein, consumer's actual purchasing behaviour might not always relate to their attitudes towards a retailer.

Based on our findings and the limitations we suggest the following further directions for research: The deliberate decision for an exploratory two-step analysis approach could be investigated by a structural equation model with the benefit of simultaneously testing the relative impact of the drivers of Consumer Value.

Furthermore, potential moderators could be considered when estimating our extended model in order to see whether the size of effects differ between several sample splits based on demographics, psychographics or behavioural variables, e.g. store format patronage.

\section{Literature}

Aastrup, J., Kotzab, H., Grant, D.B., Teller, C. and Mogens, Bjerre, M. (2008). A model for structuring efficient consumer response measures. International Review of Retail, Distribution and Consumer Research, 36 (8), pp. 590-606.

Aastrup, J., Grant, D.B. and Bjerre, M. (2007). 'Value Creation and Category Management through Retailer-Supplier Relationship', International Review of Retail, Distribution and Consumer Research, 17 (5), pp. 523-541.

AC Nielsen (2006). Consumer Centric Category Management. How to Increase Profits by Managing Categories based on Consumer Needs, Hoboken: Wiley\&Sons.

AC Nielsen (2006a). Handel in Österreich. Basisdaten 2006

Ailawadi, K. L., Neslin, S. A. and Gedenk, K. (2001). 'Pursuing the Value-Conscious Consumer: Store Brands Versus National Brand promotions', Journal of Marketing, 65 (1), pp. 71-89.

Baker, J. A., Parasuraman, A., Grewal, D. and Voss, G. B. (2002). 'The Influence of Multiple Store Environment Cues on Perceived Merchandise Value and Patronage Intentions', Journal of Marketing, 66 (2), pp. 120-141.

Basuroy, S., Mantrala, M. K. and Walters, R. G. (2001). 'The Impact of Category Management on Retailer Prices and Performance: Theory and Evidence', Journal of Marketing, 65 (4), pp. 16-32.

Berekoven, L. (1995). Erfolgreiches Einzelhandelsmarketing - Grundlagen und Entscheidungshilfen. München: Beck

Borchert, S. (2001). Führung von Distributionsnetzwerken. Wiesbaden: Gabler. 
Broniarczyk, S, M., Hoyer, W. D. and McAlister, L. (1998). 'Consumers Perceptions of the Assortment Offered in a Grocery Category: The Impact of Item Reduction', Journal of Marketing Research, 35 (2), pp. 166-176.

Churchill, G. A. and Iacobucci, D. (2005). Marketing Research - Methodological Foundations, Mason/Ohio: South-Western.

Corsten, D. (2004). Efficient Consumer Response Adoption. Theory, Model and Empirical Results. Bern: Haupt.

Dapiran, G.P. and Hogarth-Scott, S. (2003). 'Are co-operation and trust being confused with power? An analysis of food retailing in Australia and the UK', International Journal of Retail and Distribution Management, 31 (5), pp. 256267.

De Kervenoael, R., Soopramanien, D., Elms, J. and Hallsworth, A. (2006). 'Exploring value through integrated service solutions: The case of e-grocery shopping', Managing Service Quality, 16 (2), pp. 185-202.

Desrochers, D. and Nelson, P. (2006). 'Adding consumer behavior insights to category management: Improving item placement decisions', Journal of Retailing, 82 (4), pp. 357-365.

Dewsnap, B. and Hart, C. (2004), Category management: a new approach for fashion marketing? European Journal of Marketing, 38 (7), pp. 809-834.

Dhar, S. K., Hoch, S. J. and Kumar, N. (2001). 'Effective category management depends on the role of the category', Journal of Retailing, 77 (2), pp. 155-164.

Doods, W. B., Monroe, K. B. and Grewal, D. (1991). 'Effects of Price, Brand, and Store Information on Buyers’ Product Evaluations', Journal of Marketing Research, 28 (3), pp. 307-319.

Dupre, K. and Gruen, T. W. (2004). 'The use of category management practices to obtain a sustainable competitive advantage in the fast-moving-consumergoods industry', Journal of Business \& Industrial Marketing, 19 (7), pp. 444459.

Dussart, C. (1998). 'Category management: Strengths, limits and developments', European Management Journal, 16 (1), pp. 50-62.

ECR Europe (2009). Global Scorecard on www.ecrnet.org/.

ECR Europe (2007). ECR-Congress Hamburg (September 11-12, 2007). Category Management - Praxisorientierte Einstiegshilfe und Nutzenbetrachtung, Presentation by Klafsak and Klüsener.

ECR Europe (2006). European ECR-Congress Stockholm (May 29-31, 2006). Podium-Discussion following the Presentation Category Management Innovation and Diversity across Europe.

ECRE (Efficient Consumer Response Europe) (2000). The Essential Guide to Day-toDay Category Management. Andersen Consulting.

ECRE (Efficient Consumer Response Europe) (1999). Consumer Value Measurement. Roland Berger \& Partners, Price Waterhouse Coopers.

ECRE (Efficient Consumer Response Europe) (1999a). How to implement Consumer Enthusiasm. Strategic Consumer Value Management, Roland Berger \& Partners.

ECRE (Efficient Consumer Response Europe) (1998). How to create consumer enthusisam - Roadmap to growth, Roland Berger \& Partners.

ECRE (Efficient Consumer Response Europe) (1997). Category Management. Best Practises Report. The Partner Group \& Roland Berger International Management Consultants. 
Erdem, T. and Swait, J. (1998). 'Brand Equity as a Signaling Phenomenon', Journal of Consumer Psychology, 7 (2), pp. 131-157.

Fassnacht, M., Moeller, S. and Ettinger, A. (2009). Consequences Of Shopping Convenience. Paper presented at the EMAC Conference. May 28, 2009. Nantes, France.

Fernie, J. (2009). Relationships in the Supply Chain. In: Logistics \& Retail Management, eds. Fernie, J. and Sparks, L., pp. 38-63, London and Philadelphia: Kegan Page.

Finne, S. and Sivonen, H. (2009). The retail value chain. How to gain competitive advantage through Efficient Consumer Response (ECR) strategies, London and Philadelphia: Kogan Page.

Food Marketing Institute (1993). Efficient Consumer Response - Enhancing Consumer Value in the Grocery Industry. Washington, DC

Glasman, L.R. and Albarracin, D. (2006). 'Forming Attitudes That Predict Future Behaviour: A Meta-Analysis of the Attitude-Behaviour Relation', Psychological Bulletin, 132 (5), pp. 778-822.

Gilbert, D. (2003). Retail Marketing Management. London: Prentice Hall

Grant, D. B., Teller, C. and Teller, W. (2005). 'Hidden' Opportunities and Benefits in Using Web-based Business-to-Business Surveys', International Journal of Market Research, 47 (6), pp. 641-666.

Grewal, D., Krishnan, R., Levy, M.D. and Munger, J. (2006). Retail Success and Key Drivers. In: Retailing in the 21st century, eds. Krafft, M. and Mantrala, M.K., pp. 13-26, Berlin.

Grewal, D., Levy, M., Mehrotra, A. and Sharma, A. (1999). 'Planning Mechadising Decisions to Account for Regional and Product Assortment Differences', Journal of Retailing, 75 (3), pp. 405-424.

Gruen, T. W. and Shah, R. H. (2000). 'Determinants and Outcomes of Plan Objectivity and Implementation in Category Management Relationships', Journal of Retailing, 74 (4), pp. 483-510.

GS1 Germany (2008). Category Management - Einbindung, Umsetzung und die Zusammenhänge im Unternehmen. Preliminary results issued by GS1 Germany, Cologne.

Handelman, J. M. and Arnold, S. J. (1999). 'The Role of Marketing Actions with a Social Dimen-sion: Appeals to the Institutional Environment', Journal of Marketing, 63 (3), pp. 33-48.

Henard, D. H. and Szymanski, D. M. (2001). 'Why Some New Products Are More Successful Than Others', Journal of Marketing Research, 38 (3), pp. 362-375.

Hingley, M.K. (2005), 'Power to all our friends? Living the imbalance in supplierretailer relationships’, Industrial Marketing Management, 34, pp. 848-858.

Holbrook, M. B. (1994). The Nature of Customer Value, In: Service Quality - New Directions in Theory and Practice, eds. Rust, R.T. and Oliver, R.L. pp. 21-71, California: Sage Publications.

Holweg, C. (2009). Consumer Value im Category Management-Modell nach ECR. Kritische Diskussion und empirische Evaluierung. Wiesbaden: Gabler

Holzkämper, O. (1999). Category Management: Strategische Positionierung des Handels. Band 56, Göttingen: GHS Göttingen.

IGD (2006). Report Category Management 2006, Institute of Grocery Distribution, UK. 
Johnson and Pinnington (1998). Supporting the Category Management challenge: How research can contribute, Journal of the Market Research Society, 40 (1), pp.33-54

Kahn, B. E. and McAlister, L. (1997). Grocery Revolution. The New Focus on the Consumer, New York: Addison-Wesley.

Kamakura, W. A. and Kang, W. (2007). 'Chain-wide and store-level analysis for cross-category management’, Journal of Retailing, 83 (3), pp. 159-170.

Kotzab, H. (1999). 'Improving supply chain performance by efficient consumer response? A critical comparison of existing ECR appoaches', Journal of Business \& Industrial Marketing, 14 (4/5), pp. 364-377.

Kotzab, H. and Teller, C. (2003). Value-adding parnterships and co-opetition models in the grocery industry, International Journal of Physical Distribution \& Logictics Management, 33 (3), pp. 268-281.

Kumar, V. and Reinartz, W. J. (2006). Customer Relationship Management. A Databased Approach. Hoboken, NJ: John Wiley \& Sons.

Kumar, V. and Shah, D. (2004). 'Building and sustaining profitable customer loyalty for the 21st century', Journal of Retailing, 80 (4), pp. 317-330.

Kurnia, S., and Johnston, R.B. (2003). 'Adoption of efficient consumer response: key issues and challenges in Australia', Supply Chain Management: An International Journal, 8 (3), 251-262.

Kurtulus, M. and Toktay, B.L. (2005). 'Category captainship: Who wins, who loses?', ECR Journal: International Commerce Review, 4 (2), pp. 27-33.

Laurent, M. (1996). Vertikale Kooperationen zwischen Handel und Industrie. Frankfurt: Deutscher Fachverlag.

Levy, M. and Weitz, B. A. (2006). Retailing Management. Boston, Mass.: Mc Graw Hill.

Lindblom, A. and Olkkonen, R. (2008). 'An analysis of suppliers' roles in category management collaboration', Journal of Retailing and Consumer Services, 15, pp. 1-8.

Lindblom, A. and Olkkonen, R. (2006). 'Category management tactics: an analysis of manufacturers' control', International Journal of Retail and Distribution Management, 34 (6), pp. 482-496.

Luo, Xueming and Bhattacharya, L.L (2006). "Corporate Social Responsibility, Customer Satisfaction, and Market Value”, Journal of Marketing, 70 (4), pp. $1-18$.

Mathews, R. (1995). Category Management is a strategy for all seasons, yet fully realized and practised in none, Progressive Grocer, August 4, Editorial

Moll, C. (2000). Efficient Consumer Response: Neue Wege einer erfolgreichen Kooperation zwischen Industrie und Handel, Frankfurt: Dt. Fachverlag.

Mollá, A., Múgica, J.M. and Yagüe, M. (1998). Category Management and consumer choice, The International Review of Retail, Distribution and Consumer Research, 8 (2), pp. 225-241.

Müller-Hagedorn, L. and Zielke, St. (2000). Category Management, In Handbuch Produktmanagment. Strategieentwicklung - Produktplanung - Organisation Kontrolle, eds. Albers., S. and Hermann, A., pp. 859-882, Wiesbaden.

Narasimhan, C., Neslin, S. A. and Sen, S. K. (1996). 'Promotional Elasticities and Category Characteristics', Journal of Marketing, 60 (1), pp. 17-30.

Parasuraman, A. (1997). Reflections on Gaining Competitive Advantage Through Customer Value, Journal of the Academy of Marketing Science, 25 (2), pp. 154-161. 
Reichheld, F.F. (2003). The one number you need to grow, Harvard Business Review, December 2003, pp. 46-54

Reinartz, W. J. and Kumar, V. (1999). 'Store-, Market-, and Consumer Characteristics: The Drivers of Store Performance’, Marketing Letters, 10 (1), pp. 5-22.

Reutterer, T. and Teller, C. (2009), Store format choice and shopping trip types, International Journal of Retail and Distribution Management, forthcoming.

Richardson, P. S., Dick, A. S. and Jain, A. K. (1994). 'Extrinsic and Intrinsic Cue Effects on Perception of Store Brand Equity’, Journal of Marketing, 58 (4), pp. 28-36.

Rondán Cataluña, F., Navarro García, A. and Phau, I. (2006). The Influence of Price and Brand Loyalty on Store Brands versus national Brands, International Journal of Retail, Distributionon and Consumer Research, 16 (4), pp. 433452.

Rudolph, T. and Kotouc, A. (2007). Konsumentenreaktion auf eine Sortimentsreduktion. In Theoretische Fundierung und praktische Relevanz der Handelsforschung, eds. Marcus Schuckel, Waldemar Toporowski, pp. 171-189, Wiesbaden: Gabler

Schmickler, M. and Rudolph, T. (2002). Erfolgreiche ECR-Kooperationen. Vertikales Marketing zwischen Industrie und Handel, Neuwied, Kriftel: Luchterhand.

Schroeder, H. (2001). Wer hat bei Category Management an Efficient Shelf Presentation gedacht? - Informationen für kundenorientierte Flächenzuteilung und Warenpräsentation im Lebensmittel-Einzelhandel. In Jahrbuch Handelsmanagement 2001, eds. Dieter Ahlert, Olbrich Rainer, Hendrik Schroeder, pp. 261-291, Frankfurt: Deutscher Fachverlag.

Schroeder, H. and Feller, M. (2000). Category Management: Wieviel Consumer Insight hat der Handel tatsächlich? Online, http://www.marketing.uniessen.de/praxis/publikationen/ infos/ap6info.pdf.

Seifert, D. (2001). Efficient Consumer Response - Strategische Erfolgsfaktoren für die Wertschöpfungspartnerschaft von Industrie und Handel, München: Mering/Hampp.

Shoemaker, St. and Lewis, R.C. (1999). Customer loyality: the future of hospitality marketing, International Journal of Hospitality Management, 18, pp. 345-370.

Sirohi, N., McLaughlin, E.W. and Wittink, D.R. (1998). 'A Model of Consumer Perceptions and Store Loyalty Intentions for a Supermarket Retailer', Journal of Retailing, 74 (2), pp. 223-245.

Sivadas, E. and Dwyer, F. R. (2000). 'An examination of Organizational Factors Influencing New Product Success in Internal and Alliance Based Processes', Journal of Marketing, 64 (1), pp. 31-49.

Sweeney, J. C. and Soutar, G. N. (2001). 'Consumer perceived value: The development of a multiple item scale', Journal of Retailing, 77 (2), pp. 203220.

Teller, C., Reutterer, T. and Schnedlitz, P. (2008). Hedonic and Utilitarian Shopper Types in Evolved and Created Retail Agglomerations, International Review of Retail, Distribution and Consumer Research, 18 (3), pp. 283-309.

Teller, C., Kotzab, H. and Grant, D. B. (2006). The Consumer Direct Services Revolution in Grocery Retailing: An Exploratory Investigation, Managing Service Quality Journal, 16 (1), pp. 78-96. 
Teller, C. and Reutterer, T. (2008). The Evolving Concept of Retail Attractiveness: What makes retail agglomerations attractive when customers shop at them? Journal of Retailing and Consumer Services, 15 (3), pp. 127-143.

Tietz, B. (1993). Der Handelsbetrieb - Grundlagen und Unternehmenspolitik, Frankfurt am Main: Vahlen.

Van Kenhove, P., De Wulf, K. and Van Waterschoot, W. (1999). 'The impact of Task Definition on Store Attribute Salience and Store Choice', Journal of Retailing, 75 (1), pp. 125-137.

Verbeke, W., van Ginkel, X., Borghgraef, St. and Farris, P. (2000). An exploration of in-store brand-extension commitment efforts: or is brand loyalty always a good thing to have?, International Review of Retail, Distribution and Consumer Research, 10 (1), pp. 23-39.

Verhoef, P. C., van Doorn, J. and Dorotic, M. (2007). 'Customer Value Management. An Overview and Research Agenda'. Marketing - Journal of Research and Management, (2), pp. 105-120.

Woodruff, R. B. (1997). Customer Value: The Next Source for Competitive Advantage, Journal of the Academy of Marketing Science, 25 (2), pp. 139-53.

Woodside, A. G. and Trappey, R. J. I. (1992), Finding out why customers shop your store and buy your brand: Automatic cognitive processing models of primary choice, Journal of Advertising Research, 32 (6), pp. 59-78.

Wuest, P. and KSA (1996). Ergebnisse einer KSA-Befragung. Der Status von Catman in Europa versus USA, KSA - News/Category Management, Nr. 1.

Zeithaml, V. A., Berry, L. L. and Parasuraman, A. (1996). 'The Behavioral Consequences of Service Quality’, Journal of Marketing, 60 (2), pp. 31-46.

Zeithaml, V. A. (1988). 'Consumer Perceptions of Price, Quality and Value: A Means-End Model and Synthesis of Evidence', Journal of Marketing, 52 (3), pp. 2-22.

Zielke, St. (2001): Kundengerechte Sortimentsgliederung am Point of Sale. Ansätze zur Erhebung kognitiver Strukturen als Richtgröße für Warenplatzierung und Category Management, Marketing-ZFP, 2 (2), pp. 100-116.

1 The unexpected appearance of loyalty programs in this factor can be interpreted in a way that consumers already regard this extensively used promotional tool as part of the Assortment/Quality/Service dimension of a retailer.

2 An interpretation of the un-standardised regression coefficient indicates that a change in rating on for example Personnel/Image by one rating point would change the absolute spending of a household at a retailer by $€ 160$, i.e. a remarkable 5,4\%.

3 Even the consideration of demographic indicators, i.e. such as household size, income or age, results in a $\mathrm{R}^{2}$ of .150 at a maximum. 